\title{
PENGARUH UKURAN PERUSAHAAN, KEPUTUSAN INVESTASI, KEPUTUSAN PENDANAAN, KEBIJAKAN DIVIDEN, DAN PROFITABILITAS TERHADAP NILAI PERUSAHAAN
}

\author{
Yetty Murni1 \\ Email: yettymurni@gmail.com
}

Hotman Fredy2

Savena Anugerahwati3

\begin{abstract}
This research is to examine and analyze the impact of firm size, investment decision, funding decision, dividend policy, and profitability to value of the firm to the property, real estate and building constraction companies that is listing in Indonesian Stock Exchange (IDX) in the year of 2012-2016. This sample research is taken by purposive sampling technique, so as to get as many 17 samples of property, real estate, and building constraction companies that is listing in Indonesian Stock Exchange (IDX) in the year of 20122016. Analysis method that is used multiple linear regression.The result of the research is shown that funding decision, dividend policy and profitability is impacted to the value of the firm, while the firm size and investment decision is not impacted to the value of the firm.
\end{abstract}

Keywords: firm size, investment decision, funding decision, dividend policy, profitability, the firm value, multiple linear regression

\section{PENDAHULUAN}

\subsection{Latar Belakang}

Persaingan usaha yang semakin ketat mendorong perusahaan untuk mampu bersaing secara global dalam meningkatkan nilai perusahaan. Persaingan bisnis di Indonesia saat ini telah menunjukkan kemajuan yang pesat dengan semakin bertambahnya jumlah perusahaan dari hari ke hari. Berbagai jenis perusahaan hadir dalam bidang yang berbeda-beda seperti bidang jasa, manufaktur, dagang, dan lainnya yang saling bersaing untuk dapat bertahan dan menjadi yang terbaik. Apalagi, saat ini Indonesia dihadapkan pada serangkaian tantangan yang cukup

\footnotetext{
${ }^{1}$ Corresponding author: Fakultas Ekonomi dan Bisnis, Universitas Pancasila. Alamat: Jl. Srengseng Sawah, Jagakarsa, Jakarta Selatan 12640

${ }^{2}$ Fakultas Ekonomi dan Bisnis, Universitas Pancasila. Alamat: Jl. Srengseng Sawah, Jagakarsa, Jakarta Selatan 12640
} 
kompleks. Salah satu tantangan yaitu MEA (Masyarakat Ekonomi ASEAN) yaitu kesepakatan antar negara-negara ASEAN di bidang tenaga kerja. Hal ini juga berdampak terhadap perekonomian pasar modal yang menjalankan perspektif keterbukaan dan daya saing sektor pasar modal Indonesia sehingga mendorong masing-masing perusahaan untuk melakukan berbagai strategi agar terhindar dari kebangkrutan.

Pasar modal Indonesia yang dikategorikan sebagai pasar modal yang sedang tumbuh memiliki potensi yang tinggi untuk memberi kontribusi dalam ekonomi Indonesia. Bursa Efek Indonesia menjadi acuan pasar modal di Indonesia, seperti diketahui bahwa krisis ekonomi Indonesia berdampak pada nilai fundamental perusahaan, khususnya perusahaan yang listing di pasar modal. Nilai perusahaan tercermin dari harga saham yang dimiliki perusahaan terkait (Margaretha dalam Sumanti dan Mangantar 2015). Harga saham di pasar modal terbentuk berdasarkan kesepakatan antara permintaan dan penawaran investor, sehingga harga saham merupakan fair price yang dapat dijadikan sebagai proksi nilai perusahaan. Bila harga saham meningkat berarti nilai perusahaan meningkat (Hermuningsih dan Wardani 2009).

Ukuran dari sebuah perusahaan juga ikut menentukan nilai perusahaan. Ukuran perusahaan (size) merupakan suatu indikator dari kekuatan finansial suatu perusahaan (Hermuningsih 2012). Perusahaan besar lebih memiliki kepercayaan investor dibandingkan dengan perusahaan kecil karena perusahaan besar dianggap memiliki kondisi yang stabil. Sehingga memudahkan perusahaan dalam mendapatkan modal. Seperti yang diungkapkan Dewi dan Wirajaya (dalam Sari dan Priyadi 2016) semakin besar ukuran atau skala perusahaan maka akan semakin mudah pula perusahaan memperoleh sumber pendanaan baik yang bersifat internal maupun eksternal. Semakin baik dan semakin banyaknya sumber dana yang diperoleh, maka akan mendukung operasional perusahaan secara maksimum, sehingga akan meningkatkan harga saham dari perusahaan (Pantow et al. 2015).

Menurut Hidayat (dalam Verawaty et al. 2016), keputusan investasi merupakan faktor penting dalam fungsi keuangan perusahaan, di mana nilai perusahaan sematamata ditentukan oleh keputusan investasi. Tujuan dilakukannya keputusan investasi adalah mendapat laba yang besar dengan risiko yang dapat dikelola dengan harapan dapat mengoptimalkan nilai perusahaan, yang berarti menaikkan kemakmuran pemegang saham. Dengan demikian semakin tinggi keuntungan perusahaan semakin tinggi nilai perusahaan, yang berarti semakin besar kemakmuran yang akan diterima oleh pemilik perusahaan.

Keputusan pendanaan didefinisikan sebagai keputusan yang menyangkut komposisi pendanaan yang dipilih oleh perusahaan (Darminto 2010). Sudana (2011) menyatakan, keputusan pendanaan berkaitan dengan proses pemilihan sumber dana yang dipakai untuk membelanjai investasi yang direncanakan dengan berbagai alternatif sumber dana yang tersedia, sehingga diperoleh suatu kombinasi pembelanjaan yang paling efektif. Alternatif pendanaan yang dilakukan oleh perusahaan dapat berasal dari beberapa sumber, hutang (kewajiban-kewajiban), dan ekuitas.

Kebijakan dividen dapat dihubungkan dengan nilai perusahaan. Kebijakan deviden adalah untuk menentukan berapa banyak keuntungan yang akan diperoleh pemegang saham. Keuntungan yang akan diperoleh pemegang saham akan menentukan kesejahteraan para pemegang saham yang merupakan tujuan utama 
perusahaan. Pembayaran dividen yang semakin besar merupakan salah satu indikator nilai perusahaan (Wahyudi dalam Yuniati et al. 2016)

Nilai perusahaan dapat pula dipengaruhi oleh besar kecilnya profitabilitas yang dihasilkan oleh perusahaan. Dalam penelitian ini rasio profitabilitas diukur dengan Return on Equity (ROE). Return on Equity (ROE) merupakan rasio yang menunjukkan seberapa besar kemampuan perusahaan dalam menghasilkan laba bersih untuk pengembalian ekuitas terhadap pemegang saham.

Berdasarkan uraian tersebut, maka penelitian ini diberi judul "Pengaruh Ukuran Perusahaan, Keputusan Investasi, Keputusan Pendanaan, Kebijakan Dividen, dan Profitabilitas Terhadap Nilai Perusahaan".

\subsection{Tujuan Penelitian}

Adapun tujuan yang ingin dicapai dalam penelitian ini yaitu:

a. Untuk menguji dan menganalisis pengaruh ukuran perusahaan terhadap nilai perusahaan.

b. Untuk menguji dan menganalisis pengaruh keputusan investasi terhadap nilai perusahaan.

c. Untuk menguji dan menganalisis pengaruh keputusan pendanaan terhadap nilai perusahaan.

d. Untuk menguji dan menganalisis pengaruh kebijakan dividen terhadap nilai perusahaan.

e. Untuk menguji dan menganalisis pengaruh profitabilitas terhadap nilai perusahaan.

\section{TINJAUAN PUSTAKA}

\subsection{Teori Keagenan (Agency Teory)}

Teori keagenan atau agency theory dikemukakan oleh Michael C. Jensen dan William H. Meckling pada tahun 1976. Jensen dan Meckling (dalam Verawaty et al. 2016) menggambarkan hubungan agency sebagai suatu kontrak di bawah satu atau lebih (principal) yang melibatkan orang lain (agent) untuk melaksanakan beberapa layanan bagi mereka dengan melibatkan pendelegasian wewenang pengambilan keputusan kepada agen. Teori keagenan merupakan basis teori yang mendasari praktek bisnis perusahaan yang dipakai selama ini. Prinsip utama teori ini menyatakan adanya hubungan kerja antara pihak yang memberi wewenang (prinsipal) dengan yang menerima wewenang (agen). Dengan demikian, inti dari hubungan keagenan adalah terdapat pemisahan antara kepemilikan dan pengelolaan perusahaan. Agency theory menjelaskan adanya benturan kepentingan antara prinsipal dan agen.

Pada teori keagenan yang disebut prinsipal adalah pemegang saham dan yang disebut agen adalah manajemen yang mengelola perusahaan. Prinsipal diasumsikan hanya tertarik pada pengembalian keuangan yang diperoleh dari investasi mereka pada perusahaan, sedangkan agen diasumsikan akan menerima kepuasan tidak hanya dari kompensasi keuangan tetapi juga dari tambahan lain yang terlibat dalam hubungan keagenan.

\subsection{Teori Sinyal (Signalling Theory)}

Teori sinyal didasarkan pada asumsi bahwa informasi yang diterima oleh masing-masing pihak tidak sama. Dengan kata lain, teori sinyal berkaitan dengan 
asimetri informasi. Teori sinyal menunjukkan adanya asimetri informasi antara manajemen perusahaan dengan pihak-pihak yang berkepentingan dengan informasi. Untuk itu, manajer perlu memberikan informasi bagi pihak-pihak yang berkepentingan melalui penerbitan laporan keuangan. Teori sinyal mengemukakan tentang bagaimana seharusnya sebuah perusahaan memberikan sinyal kepada pengguna laporan keuangan. Sinyal ini berupa informasi mengenai apa yang sudah dilakukan oleh manajemen untuk merealisasikan keinginan pemilik. Sinyal dapat berupa promosi atau informasi lain yang menyatakan bahwa perusahaan tersebut lebih baik daripada perusahaan lain (Ustianti 2015).

\subsection{Nilai Perusahaan}

Nilai perusahaan merupakan persepsi investor terhadap tingkat keberhasilan perusahaan yang terkait erat dengan harga sahamnya. Harga saham yang tinggi membuat nilai perusahaan juga tinggi, dan meningkatnya kepercayaan pasar tidak hanya terhadap kinerja perusahaan saat ini namun juga pada prospek perusahaan di masa mendatang. Harga saham yang digunakan umumnya mengacu pada harga penutupan (closing price), dan merupakan harga yang terjadi pada saat saham diperdagangkan di pasar (Hermuningsih 2012). Menurut Brigham dan Ehrhardt (2013), rumus untuk menghitung Price to Book Value (PBV) yaitu:

$$
P B V=\frac{\text { Market Price Per Share }}{\text { Book Value Per Share }}
$$

\subsection{Ukuran Perusahaan}

Febria et al (dalam Surjadi dan Tobing 2016) menyebutkan bahwa ukuran secara umum dapat diartikan sebagai perbandingan besar kecilnya suatu objek. Sedangkan perusahaan adalah suatu organisasi yang didirikan oleh seseorang atau sekelompok orang atau badan lain yang kegiatannya adalah melakukan produksi dan distribusi guna memenuhi kebutuhan ekonomi manusia. Ukuran Perusahaan adalah suatu skala di mana dapat diklasifikasikan besar kecilnya perusahaan menurut berbagai cara, antara lain: total aktiva, log size, nilai pasar saham (Badruddien et al. 2017; Winarno dan Tjahjadi 2017). Dalam penelitian ini ukuran perusahaan diukur menggunakan logaritma natural (Ln) dari total aset yang dimiliki perusahaan yang dapat dirumuskan sebagai berikut:

$$
\text { SIZE = (Ln) Total Assets }
$$

\subsection{Keputusan Investasi}

Keputusan investasi merupakan suatu keputusan yang diambil perusahaan untuk menentukan investasi jangka pendek atau jangka panjang. Keputusan investasi didefinisikan sebagai kombinasi antara aktiva yang dimiliki (assets in place) dengan pilihan investasi dimasa yang akan datang dengan net present value positif. IOS tidak dapat diobeservasi secara langsung, sehingga dalam perhitungannya menggunakan proksi (Kallapur dan Trombley dalam Fenandar dan Raharja 2012). Proksi IOS dalam penelitian ini adalah CPA/BVA atau Ratio Capital Expenditure to Book Value of Asset dengan rumus sebagai berikut: 


$$
\mathrm{CPA} / \mathrm{BVA}=\frac{\text { Assets Growth }}{\text { Total Assets }}
$$

\subsection{Kebijakan Dividen}

Kebijakan dividen adalah keputusan tentang seberapa banyak laba saat ini yang akan dibayarkan sebagai dividen daripada ditahan untuk diinvestasikan kembali dalam perusahaan (Herawati 2013). Menurut Mandagi (dalam Verawaty et al. 2016), kebijakan dividen menentukan berapa banyak laba yang harus dibayar kepada pemegang saham dan berapa banyak yang harus ditanam kembali di dalam perusahaan (laba ditahan). Laba ditahan merupakan salah satu sumber dana internal. Kebijakan dividen perusahaan dapat dilihat dari nilai Dividend Payout Ratio (DPR). DPR menunjukkan rasio dividen yang dibagikan perusahaan dengan laba bersih yang dihasilkan oleh perusahaan. Menurut Brigham dan Houston (2010), DPR dapat dihitung dengan menggunakan rumus:

$$
D P R=\frac{\text { Dividend Per Share }}{\text { Earning Per Share }}
$$

\subsection{Profitabilitas}

Rasio profitabilitas adalah sekelompok rasio yang menunjukkan gabungan efek-efek dari likuiditas, manajemen aktiva, dan hutang pada hasil-hasil operasi (Brigham dan Ehrhardt 2013). Rasio profitabilitas mengukur kemampuan perusahaan dalam menghasilkan keuntungan dari kegiatan bisnis yang dilakukan.

Pada penelitian ini, alat ukur yang digunakan dalam mengukur rasio profitabilitas yaitu Return on Equity (ROE). Return on equity (ROE) merupakan tingkat pengembalian ekuitas pemilik perusahaan. Ekuitas pemilik adalah jumlah aktiva bersih perusahaan. Sehingga perhitungan ROE sebuah perusahaan dapat dihitung dengan menggunakan rumus:

$$
R O E=\frac{\text { Net Income }}{\text { Common Equity }}
$$

\subsection{Hipotesis Penelitian}

$\mathbf{H}_{\mathbf{1}}=$ Ukuran perusahaan berpengaruh terhadap nilai perusahaan

$\mathbf{H}_{2}=$ Keputusan investasi berpengaruh terhadap nilai perusahaan

$\mathbf{H}_{3}=$ Keputusan pendanaan berpengaruh terhadap nilai perusahaan

$\mathbf{H}_{\mathbf{4}}=$ Kebijakan dividen berpengaruh terhadap nilai perusahaan

$\mathbf{H}_{\mathbf{5}}=$ Profitabilitas berpengaruh terhadap nilai perusahaan

\section{METODE PENELITIAN}

\subsection{Populasi dan Sampel}

Populasi dalam penelitian ini adalah seluruh perusahaan industri jasa sektor properti, real estate, dan konstruksi bangunan yang terdaftar di Bursa Efek Indonesia (BEI) periode 2012-2016 yaitu sebanyak 69 perusahaan. Pengambilan sampel yang digunakan dalam penelitian ini adalah teknik purposive sampling, yaitu metode pengambilan sampel kriteria-kriteria atau sesuai dengan pertimbangan-pertimbangan tertentu yang telah ditetapkan oleh peneliti terhadap objek yang akan diteliti.

Kriteria pengambilan sampel dalam penelitian ini adalah sebagai berikut : 
a. Perusahaan properti, real estate dan konstruksi bangunan yang terdaftar di BEI pada periode 2012 - 2016.

b. Perusahaan properti, real estate dan konstruksi bangunan menerbitkan Laporan Keuangan Konsolidasian (audited) untuk periode yang berakhir pada 31 Desember selama periode penelitian.

c. Perusahaan tidak delisting dari bursa efek selama periode penelitian.

d. Perusahaan properti, real estate, dan konstruksi bangunan yang membagikan dividen kas selama periode penelitian.

e. Perusahaan properti, real estate, dan konstruksi bangunan yang memiliki pertumbuhan aktiva selama periode penelitian.

f. Perusahaan properti, real estate, dan konstruksi bangunan yang memiliki laba positif selama periode penelitian.

Berdasarkan kriteria di atas maka diperoleh 17 perusahaan sebagai sampel dalam penelitian ini. Total sampel yang dilakukan untuk periode 2012-2016 diperoleh sebanyak 85 pengamatan.

\subsection{Definisi Operasional Variabel}

Tabel 1. Operasionalisasi Variabel

\begin{tabular}{|c|c|c|c|c|}
\hline NO & Variabel & Sub Variabel & Indikator & $\begin{array}{l}\text { Skala } \\
\text { Ukur }\end{array}$ \\
\hline 1 & $\begin{array}{c}\text { Ukuran Perusahaan } \\
\left(\mathrm{X}_{1}\right)\end{array}$ & SIZE & SIZE $=($ Ln $)$ Total Assets & Nominal \\
\hline 2 & $\begin{array}{c}\text { Keputusan Investasi } \\
\left(\mathrm{X}_{2}\right)\end{array}$ & $\begin{array}{c}\text { Ratio Capital } \\
\text { Expenditure to } \\
\text { Book Value of } \\
\text { Asset }\end{array}$ & $\mathrm{CPA} / \mathrm{BVA}=\frac{\text { Assets Growth }}{\text { Total Assets }}$ & Rasio \\
\hline 3 & $\begin{array}{c}\text { Keputusan Pendanaan } \\
\left(\mathrm{X}_{3}\right)\end{array}$ & $\begin{array}{l}\text { Debt to Equity } \\
\text { Ratio }\end{array}$ & $\mathrm{DER}=\frac{\text { Total Debt }}{\text { Total Common Equity }}$ & Rasio \\
\hline 4 & $\begin{array}{c}\text { Kebijakan Dividen } \\
\left(\mathrm{X}_{4}\right)\end{array}$ & $\begin{array}{c}\text { Dividend } \\
\text { Payout Ratio }\end{array}$ & $\mathrm{DPR}=\frac{\text { Dividend Per Share }}{\text { Earning Per Share }}$ & Rasio \\
\hline 5 & Profitabilitas (X5) & $\begin{array}{l}\text { Return On } \\
\text { Equity }\end{array}$ & $\mathrm{ROE}=\frac{\text { Net Income }}{\text { Common Equity }}$ & Rasio \\
\hline 6 & Nilai Perusahaan (Y) & $\begin{array}{c}\text { Price to Book } \\
\text { Value }\end{array}$ & $\mathrm{PBV}=\frac{\text { Market Price Per Share }}{\text { Book Value Per Share }}$ & Rasio \\
\hline
\end{tabular}

Sumber: Hasil Pengolahan Data

\subsection{Metode Analisis Data}

Analisis data mempunyai tujuan untuk menyampaikan dan membatasi penemuan-penemuan hingga menjadi data yang teratur serta tersusun dan lebih berarti. Analisis data yang dilakukan adalah analisis kuantitatif yang dinyatakan dengan angka-angka dan perhitungannya menggunakan metode standar yang dibantu dengan program IBM SPSS versi 22. Analisis data yang digunakan dalam penelitian ini adalah analisis regresi linier berganda. Analisis regresi linier berganda digunakan untuk menguji pengaruh profitabilitas, kebijakan dividen, keputusan investasi, dan 
keputusan pendanaan terhadap nilai perusahaan nilai perusahaan perusahaan properti, real estate, dan konstruksi bangunan yang listing di BEI. Sebelum analisa regresi dilakukan, maka harus diuji dulu dengan uji asumsi klasik untuk memastikan apakah model regresi digunakan tidak terdapat masalah normalitas, multikolinearitas, heteroskedastisitas, dan autokolerasi serta melakukan uji hipotesis. Jika terpenuhi maka model analisis layak untuk digunakan.

Model penelitian ini secara sistematis dapat digambarkan dengan persamaan sebagai berikut:

$$
\mathrm{Y}=\alpha+\beta 1 \mathrm{SZ}+\beta 2 \mathrm{KI}+\beta 3 \mathrm{KP}+\beta 4 \mathrm{KD}+\beta 5 \mathrm{PR} \mathrm{e}
$$

Keterangan:

$\begin{array}{ll}\mathrm{Y} & =\text { Nilai Perusahaan } \\ \alpha & =\text { Konstanta } \\ \beta & =\text { Koefisien regresi } \\ \mathrm{SZ} & =\text { Ukuran Perusahaan }(\text { SIZE) } \\ \mathrm{KI} & =\text { Keputusan Investasi } \\ \mathrm{KP} & =\text { Keputusan Pendanaan } \\ \mathrm{KD} & =\text { Kebijakan Dividen } \\ \mathrm{PR} & =\text { Profitabilitas } \\ \mathrm{e} & =\text { Error Term }\end{array}$

\section{HASIL DAN PEMBAHASAN}

\subsection{Deskripsi Obyek Penelitian}

Obyek penelitian yang digunakan dalam penelitian ini adalah seluruh perusahaan industri jasa sektor properti, real estate, dan konstruksi bangunan yang terdaftar di Bursa Efek Indonesia (BEI) dari tahun 2012-2016. Sampel yang digunakan dalam penelitian ini adalah 17 perusahaan dengan total sampel penelitian sebanyak 85 sampel. Setelah dilakukan outlier, maka sampel yang di uji menjadi 76 sampel.

\subsection{Uji Asumsi Klasik}

Penelitian ini menggunakan data sekunder. Untuk mendapatkan ketepatan model yang akan dianalisis, perlu dilakukan pengujian atas beberapa persyaratan asumsi klasik yang mendasari model regresi. Setelah dilakukan uji asumsi klasik, penelitian ini telah lulus uji normalitas, multikolinearitas, heteroskedastisitas, serta autokorelasi.

\subsection{Analisis Regresi Linear Berganda}

Persamaan regresi linear berganda digunakan untuk mengetahui bentuk hubungan antara variabel nilai perusahaan dan variabel ukuran perusahaan, keputusan investasi, keputusan pendanaan, kebijakan dividen, dan profitabilitas. Hasil analisis regresi linear berganda dapat dilihat pada tabel 2. 
Tabel 2

\begin{tabular}{|c|c|c|c|c|c|c|c|}
\hline & & & Coefficients $^{\mathrm{a}}$ & & & & \\
\hline \multirow[b]{2}{*}{ Model } & \multicolumn{2}{|c|}{$\begin{array}{l}\text { Unstandardized } \\
\text { Coefficients }\end{array}$} & $\begin{array}{c}\text { Standardized } \\
\text { Coefficients }\end{array}$ & \multirow[b]{2}{*}{$\mathrm{t}$} & \multirow[b]{2}{*}{ Sig. } & \multicolumn{2}{|c|}{ Collinearity Statistics } \\
\hline & B & Std. Error & Beta & & & Tolerance & VIF \\
\hline 1 (Constant) & -4.021 & 2.339 & & -1.719 & .090 & & \\
\hline LnSIZE & .139 & .079 & .131 & 1.745 & .085 & .838 & 1.194 \\
\hline $\mathrm{KI}$ & -1.166 & .811 & -.109 & -1.438 & .155 & .824 & 1.214 \\
\hline $\mathrm{KP}$ & .256 & .079 & .247 & 3.249 & .002 & .822 & 1.216 \\
\hline KD & 3.019 & .771 & .278 & 3.917 & .000 & .944 & 1.059 \\
\hline PR & 8.471 & .991 & .630 & 8.546 & .000 & .874 & 1.144 \\
\hline
\end{tabular}

a. Dependent Variable: NP

Sumber: Idx, Data Diolah Penulis, 2018

Berdasarkan hasil analisis regresi yang disajikan pada Tabel 4, maka dapat dibuat persamaan regresi sebagai berikut:

$$
\mathrm{Y}=-4,021+0,139 \mathrm{SZ}-1,166 \mathrm{KI}+0,256 \mathrm{KP}+3,019 \mathrm{KD}+8,471 \mathrm{PR}+\mathrm{e}
$$

\subsection{Uji Hipotesis}

\subsubsection{Hasil Uji t (Uji Parsial)}

Berdasarkan hasil uji t pada Tabel 2 maka pengaruh Profitabilitas, kebijakan dividen, keputusan investasi, dan keputusan pendanaan terhadap nilai perusahaan dapat dijelaskan sebagai berikut:

a. Ukuran Perusahaan (SIZE)

Pada tabel 2 menunjukkan bahwa hasil thitung untuk ukuran perusahaan sebesar 1,745 dan probabilitas sebesar 0,085 (> 0,05), maka dapat disimpulkan bahwa variabel keputusan investasi tidak memiliki pengaruh terhadap nilai perusahaan. Sehingga hipotesis ketiga $\left(\mathrm{H}_{1}\right)$ tidak dapat dibuktikan, dengan kata lain $\mathrm{H}_{1}$ ditolak.

b. Keputusan Investasi (CPA/BVA)

Pada tabel 2 menunjukkan bahwa hasil thitung untuk keputusan investasi sebesar -1,438 dan probabilitas sebesar 0,155 (> 0,05), maka dapat disimpulkan bahwa variabel keputusan investasi tidak memiliki pengaruh terhadap nilai perusahaan. Sehingga hipotesis ketiga $\left(\mathrm{H}_{2}\right)$ tidak dapat dibuktikan, dengan kata lain $\mathrm{H}_{2}$ ditolak.

c. Keputusan Pendanaan (Debt to Equity Ratio)

Pada tabel 2 menunjukkan bahwa hasil thitung untuk keputusan pendanaan sebesar 3,249 dan probabilitas sebesar 0,002 (< 0,05), maka dapat disimpulkan bahwa variabel keputusan pendanaan memiliki pengaruh terhadap nilai perusahaan. Sehingga hipotesis keempat $\left(\mathrm{H}_{3}\right)$ dapat dibuktikan, dengan kata lain $\mathrm{H}_{3}$ diterima.

d. Kebijakan Dividen (Dividend Payout Ratio)

Pada tabel 2 menunjukkan bahwa hasil thitung untuk kebijakan dividen sebesar 3,917 dan probabilitas sebesar 0,000 $(<0,05)$, maka dapat disimpulkan bahwa variabel kebijakan dividen memiliki pengaruh terhadap 
nilai perusahaan. Sehingga hipotesis kedua $\left(\mathrm{H}_{4}\right)$ dapat dibuktikan, dengan kata lain $\mathrm{H}_{4}$ diterima.

e. Profitabilitas (Return on Equity)

Pada tabel 2 menunjukkan bahwa hasil thitung untuk profitabilitas sebesar 8,546 dan probabilitas sebesar 0,000 $(<0,05)$, maka dapat disimpulkan bahwa variabel profitabilitas memiliki pengaruh terhadap nilai perusahaan. Sehingga hipotesis pertama $\left(\mathrm{H}_{5}\right)$ dapat dibuktikan, dengan kata lain $\mathrm{H}_{5}$ diterima.

\subsubsection{Hasil Uji F (Uji Simultan)}

Tabel 3

\begin{tabular}{|l|r|r|r|r|r|}
\hline & \multicolumn{1}{|c|}{ ANOVA $^{\mathrm{a}}$} \\
Model & Squares & \multicolumn{1}{c|}{$\mathrm{df}$} & $\begin{array}{c}\text { Mean } \\
\text { Square }\end{array}$ & \multicolumn{1}{c|}{$\mathrm{F}$} & Sig. \\
\hline 1 Regression & 72.131 & 5 & 14.426 & 28.131 & $.000^{\mathrm{b}}$ \\
Residual & 35.898 & 70 & .513 & & \\
Total & 108.029 & 75 & & & \\
\hline
\end{tabular}

a. Dependent Variable: NP

b. Predictors: (Constant), PR, LnSIZE, KD, KI, KP

Sumber: Idx, Data Diolah Penulis, 2018

Berdasarkan tabel 3 di atas menunjukkan nilai $\mathrm{F}$ diperoleh sebesar 28,131. Model yang diuji baik karena memiliki tingkat signifikansi sebesar 0,000. Karena tingkat signifikansi $0,000<0,05$, maka dapat dikatakan bahwa semua variabel independen, yaitu ukuran perusahaan, keputusan investasi, keputusan pendanaan, kebijakan dividen, dan profitabilitas berpengaruh secara bersama-sama atau simultan terhadap variabel dependen yaitu nilai perusahaan.

\subsubsection{Uji Koefisien Determinasi $\left(R_{2}\right)$}

Koefisien determinasi $\left(\mathrm{R}_{2}\right)$ pada intinya mengukur seberapa jauh kemampuan model dalam menerangkan variasi variabel dependen. Hasil uji koefisien determinasi antara profitabilitas, kebijakan dividen, keputusan investasi, dan keputusan pendanaan terhadap nilai perusahaan dapat dilihat ditabel berikut:

\section{Tabel 4}

Model Summary

\begin{tabular}{|l|r|r|r|c|}
\hline Model & $\mathrm{R}$ & $\mathrm{R}$ Square & \multicolumn{1}{|c|}{$\begin{array}{c}\text { Adjusted R } \\
\text { Square }\end{array}$} & $\begin{array}{c}\text { Std. Error of the } \\
\text { Estimate }\end{array}$ \\
\hline 1 & $.817^{\mathrm{a}}$ & .668 & .644 & .7161173 \\
\hline
\end{tabular}

a. Predictors: (Constant), PR, LnSIZE, KD, KI, KP

b. Dependent Variable: NP

Sumber: Idx, Data Diolah Penulis, 2018 
Tabel 4 di atas menunjukkan nilai Adjusted $R$ Square sebesar 0,644. Hal ini menandakan bahwa variabel ukuran perusahaan, keputusan investasi, keputusan pendanaan, kebijakan dividen, dan profitabilitas dapat menjelaskan $64,4 \%$ variasi variabel nilai perusahaan. Sedangkan sisanya, yaitu 35,6\% (100\% - 64,4\%) dijelaskan oleh variabel-variabel lain yang tidak dijelaskan dalam penelitian ini.

\subsection{Pembahasan}

\subsubsection{Pengaruh Ukuran Perusahaan terhadap Nilai Perusahaan}

Berdasarkan penelitian yang telah dilakukan, variabel ukuran perusahaan tidak berpengaruh terhadap nilai perusahaan. Tidak berpengaruhnya ukuran perusahaan terhadap nilai perusahaan kemungkinan dikarenakan besarnya total aktiva sebagai ukuran perusahaan belum memberikan keyakinan kepada investor tentang kemampuan perusahaan dalam mengelola aset yang ada, sehingga ukuran perusahaan tidak mempengaruhi nilai perusahaan.

Suharli (dalam Astriani 2014) menyatakan bahwa jika perusahaan memiliki total aset yang besar, pihak manajemen akan lebih leluasa dalam mempergunakan aset yang ada di perusahaan tersebut. Kebebasan yang dimiliki manajemen ini sebanding dengan kekhawatiran yang dirasakan pemilik asetnya. Total aset yang besar akan menurunkan nilai perusahaan jika dilihat dari sisi pemilik perusahaan. Akan tetapi jika dilihat dari sisi manajemen kemudahan yang dimilikinya dalam mengendalikan perusahaan akan meningkatkan nilai perusahaan.

\subsubsection{Pengaruh Keputusan Investasi terhadap Nilai Perusahaan}

Berdasarkan penelitian yang telah dilakukan, variabel keputusan investasi tidak berpengaruh terhadap nilai perusahaan. Tidak berpengaruhnya keputusan investasi yang diproksikan dengan Investment Opportunity Set dengan nilai perusahaan yang ditemukan dalam hasil penelitian ini bisa disebabkan oleh kurang tepatnya keputusan investasi yang diambil oleh manajer pada perusahaan properti, real estate, dan konstruksi bangunan tersebut. Selain itu pertumbuhan aset yang merupakan hasil dari keputusan investasi hanya membandingkan antara aset tahun sekarang dengan aset tahun sebelumnya. Walaupun aset tahun sekarang mengalami penurunan tidak menjamin aset tahun berikutnya juga akan mengalami penurunan juga atau sebaliknya. Sehingga hal ini tidak terlalu menjadi perhatian bagi investor jika melakukan investasi.

\subsubsection{Pengaruh Keputusan Pendanaan terhadap Nilai Perusahaan}

Berdasarkan penelitian yang telah dilakukan, variabel keputusan pendanaan berpengaruh terhadap nilai perusahaan. Apabila keputusan pendanaan naik sebesar satu satuan, maka nilai perusahaan juga akan naik. Adanya pengaruh yang diberikan keputusan pendanaan menunjukkan bahwa keputusan pendanaan yang dilakukan perusahaan adalah dengan menggunakan pendanaan melalui ekuitas yang lebih banyak daripada menggunakan pendanaan melalui hutang, sehingga laba yang diperoleh akan semakin besar. Peningkatan hutang juga dapat diartikan pihak luar tentang kemampuan perusahaan untuk membayar kewajibannya di masa yang akan datang atau risiko bisnis yang rendah, sehingga penambahan hutang telah memberikan sinyal positif (Brigham dan Houston 2010). 


\subsubsection{Pengaruh Kebijakan Dividen terhadap Nilai Perusahaan}

Berdasarkan penelitian yang telah dilakukan, variabel kebijakan dividen berpengaruh terhadap nilai perusahaan. Hubungan antara kebijakan dividen dengan nilai perusahaan menunjukkan bahwa apabila perusahaan membayarkan lebih banyak dividen maka hal tersebut dapat meningkatkan nilai perusahaan, karena dengan banyaknya dividen yang dibagikan kepada para pemegang saham maka calon investor akan tertarik untuk berinvestasi pada perusahaan tersebut sehingga dapat meningkatkan nilai perusahaan. Hal tersebut sesuai dengan pernyataan Brigham dan Houston (2010) yang menyatakan bahwa investor lebih menyukai dividen dibandingkan pendapatan modal karena dividen bersifat lebih pasti dibandingkan pendapatan modal (capital gain).

\subsubsection{Pengaruh Profitabilitas terhadap Nilai Perusahaan}

Berdasarkan penelitian yang telah dilakukan, variabel profitabilitas berpengaruh terhadap nilai perusahaan. Adanya pengaruh antara profitabilitas dengan nilai perusahaan menandakan bahwa profitabilitas perusahaan sangat berpengaruh terhadap nilai perusahaan. Naiknya profitabilitas dari tahun ke tahun pada perusahaan berarti terjadi adanya kenaikan laba bersih dari perusahaan yang bersangkutan. Naiknya laba bersih dapat dijadikan salah satu indikasi bahwa nilai perusahaan juga naik karena naiknya laba bersih sebuah perusahaan yang bersangkutan akan menyebabkan harga saham yang berarti juga kenaikan dalam nilai perusahaan.

\section{KESIMPULAN, KETERBATASAN PENELITIAN, DAN SARAN}

\subsection{Kesimpulan}

Berdasarkan hasil penelitian dan pembahasan, dapat ditarik kesimpulan sebagai berikut:

a. Hasil penelitian menunjukkan bahwa variabel ukuran perusahaan tidak berpengaruh terhadap nilai perusahaan.

b. Hasil penelitian menunjukkan bahwa variabel keputusan investasi tidak berpengaruh terhadap nilai perusahaan.

c. Hasil penelitian menunjukkan bahwa variabel keputusan pendanaan berpengaruh terhadap nilai perusahaan.

d. Hasil penelitian menunjukkan bahwa variabel kebijakan dividen berpengaruh terhadap nilai perusahaan.

e. Hasil penelitian menunjukkan bahwa variabel profitabilitas berpengaruh terhadap nilai perusahaan.

\subsection{Keterbatasan Penelitian}

Penelitian ini masih mempunyai beberapa keterbatasan yaitu sebagai berikut:

a. Hanya menguji beberapa faktor yang mempengaruhi nilai perusahaan, yaitu ukuran perusahaan, keputusan investasi, keputusan pendanaan, kebijakan dividen, dan profitabilitas,

b. Penelitian yang dilakukan terbatas pada perusahaan properti, real estate dan konstruksi bangunan, sehingga kurang mewakili seluruh sektor yang ada di Bursa Efek Indonesia 


\subsection{Saran}

Berdasarkan kesimpulan dan keterbatasan penelitian yang telah dikemukakan diatas, maka saran yang dapat diberikan untuk penelitian selanjutnya adalah sebagai berikut:

a. Dengan data penelitian 5 tahun (2012-2016) menghasilkan tiga variabel independen yang memiliki pengaruh terhadap nilai perusahaan yaitu profitabilitas, kebijakan dividen, dan keputusan pendanaan, maka bagi perusahaan variabel ini dapat dijadikan acuan untuk menentukan strategi dalam meningkatkan nilai perusahaan.

b. Dapat menggunakan atau menambahkan variabel independen lainnya seperti tingkat suku bunga, risiko bisnis, dan struktur kepemilikan agar diperoleh hasil yang lebih baik lagi.

c. Memperluas sampel penelitian yang tidak hanya berfokus pada sektor industri jasa properti, real estate, dan konstruksi bangunan

\section{DAFTAR PUSTAKA}

Astriani, E. F. 2014. Pengaruh kepemilikan manajerial, leverage, profitabilitas, ukuran perusahaan dan investment opportunity set terhadap nilai perusahaan. Jurnal Akuntansi 2 (1).

Badruddien, Y., T. T. Gustyana, dan A. S. Dewi. 2017. Pengaruh Good Corporate Governance, Leverage Dan Ukuran Perusahaan Terhadap Nilai Perusahaan (studi Empiris Pada Sektor Industri Barang Konsumsi Di Bursa Efek Indonesia Periode 2012-2015). eProceedings of Management 4 (3).

Brigham, E. F., dan M. C. Ehrhardt. 2013. Financial management: Theory \& practice: Cengage Learning.

Brigham, E. F., dan J. F. Houston. 2010. Essentials of financial management: Engage Learning Asia.

Fenandar, G. I., dan S. Raharja. 2012. Pengaruh keputusan investasi, keputusan pendanaan, dan kebijakan dividen terhadap nilai perusahaan, Fakultas Ekonomika dan Bisnis.

Herawati, T. 2013. Pengaruh kebijakan dividen, kebijakan hutang dan profitabilitas terhadap nilai perusahaan. Jurnal Manajemen 2 (2):1-18.

Hermuningsih, S. 2012. Pengaruh profitabilitas, size terhadap nilai perusahaan dengan sruktur modal sebagai variabel intervening. Jurnal Siasat Bisnis 16 (2).

Surjadi, C., dan R. L. Tobing. 2016. Efek Moderasi Ukuran Perusahaan Pada

Pengaruh Good Corporate Governance terhadap Nilai Perusahaan. Jurnal Manajemen Bisnis 11 (2).

Ustianti, N. 2015. Pengaruh Struktur Modal, Kepemilikan Manajerial, Keputusan Investasi, Kebijakan Dividen, Keputusan Pendanaan dan Profitabilitas terhadap Nilai Perusahaan (Studi pada Perusahaan Keuangan dan Perbankan di BEI Tahun 2009-2013). Journal Of Accounting 1 (1).

Verawaty, V., C. I. Merina, dan I. Kurniawati. 2016. Analisis Pengembangan Corporate Value berdasarkan Keputusan Investasi dan Pendanaan, Struktur Kepemilikan serta Kebijakan Dividen pada Perusahaan Manufaktur yang 
Terdaftar di Bursa Efek Indonesia. Berkala Akuntansi dan Keuangan Indonesia $1(1)$.

Winarno, W. A., dan B. Tjahjadi. 2017. The moderating effect of industry environments on the relationship between IT asset portfolios, efficiency and innovation in the ERP context. European Research Studies Journal 20 (2):315. 


\section{LAMPIRAN}

\section{Lampiran 1}

Hasil Statistik Deskriptif

\begin{tabular}{|l|r|r|r|}
\hline & \multicolumn{1}{|c|}{ Descriptive Statistics } \\
\hline NP & \multicolumn{1}{|c|}{ Mean } & Std. Deviation & N \\
LnSIZE & 2.051001 & 1.2001589 & 76 \\
KI & 29.8323 & 1.13813 & 76 \\
KP & .179941 & .1123539 & 76 \\
KD & 1.361570 & 1.1575440 & 76 \\
PR & .187487 & .1104184 & 76 \\
\hline
\end{tabular}

Sumber: Idx, Data Diolah Penulis, 2018

\section{Lampiran 2}

Hasil Uji Multikolineritas

\begin{tabular}{|c|c|c|c|c|c|c|c|}
\hline & & & Coefficients $^{\mathrm{a}}$ & & & & \\
\hline \multirow[b]{2}{*}{ Model } & \multicolumn{2}{|c|}{$\begin{array}{c}\text { Unstandardized } \\
\text { Coefficients }\end{array}$} & \multirow{2}{*}{$\begin{array}{c}\text { Standardized } \\
\text { Coefficients } \\
\text { Beta }\end{array}$} & \multirow[b]{2}{*}{$\mathrm{t}$} & \multirow[b]{2}{*}{ Sig. } & \multicolumn{2}{|c|}{ Collinearity Statistics } \\
\hline & B & Std. Error & & & & Tolerance & VIF \\
\hline 1 (Constant) & -4.021 & 2.339 & & -1.719 & .090 & & \\
\hline LnSIZE & .139 & .079 & .131 & 1.745 & .085 & .838 & 1.194 \\
\hline $\mathrm{KI}$ & -1.166 & .811 & -.109 & -1.438 & .155 & .824 & 1.214 \\
\hline KP & .256 & .079 & .247 & 3.249 & .002 & .822 & 1.216 \\
\hline KD & 3.019 & .771 & .278 & 3.917 & .000 & .944 & 1.059 \\
\hline PR & 8.471 & .991 & .630 & 8.546 & .000 & .874 & 1.144 \\
\hline
\end{tabular}

a. Dependent Variable: NP

Sumber: Idx, Data Diolah Penulis, 2018 


\section{Lampiran 3}

Hasil Uji Heteroskedastisitas (Gambar P-Plot)

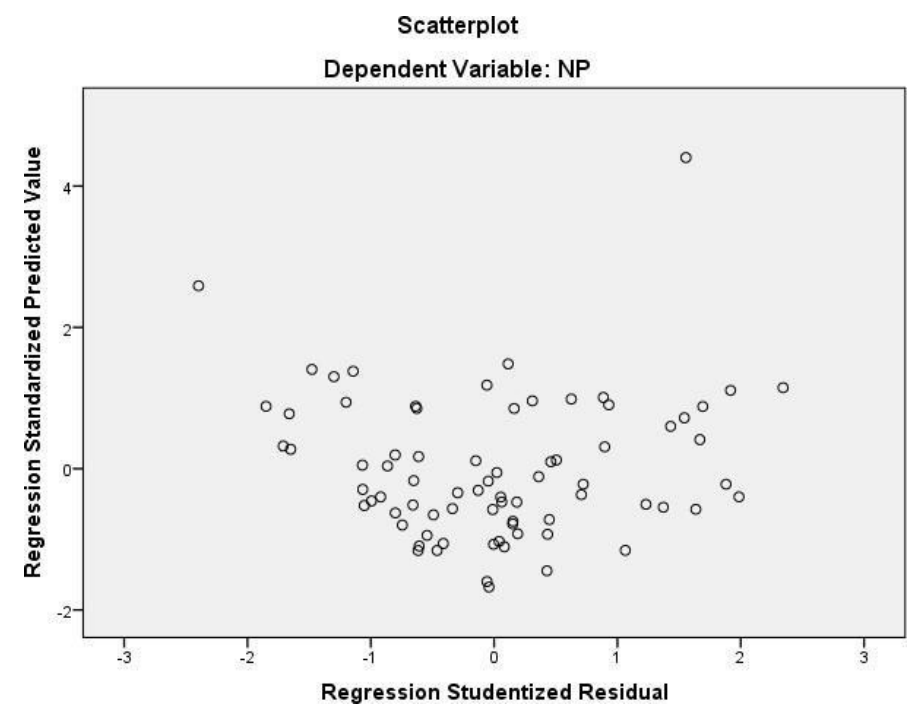

Sumber: Idx, Data Diolah Penulis, 2018

\section{Lampiran 4}

Hasil Uji Normalitas

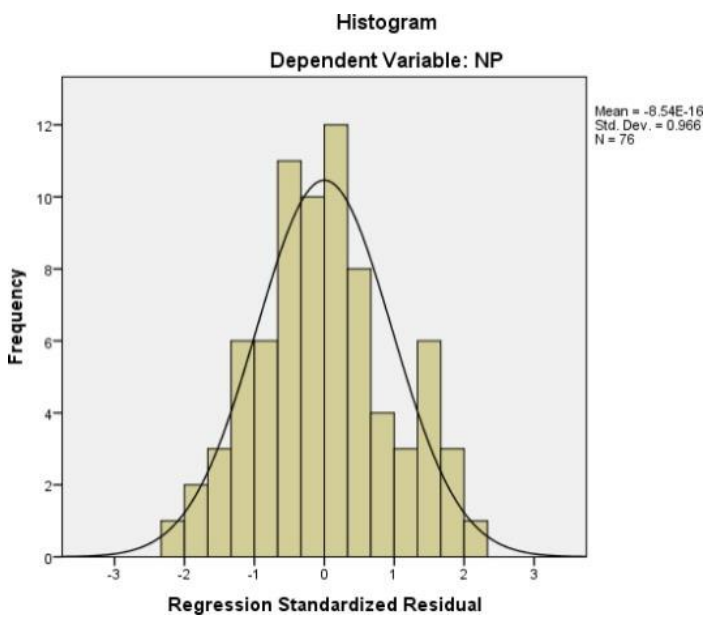

Sumber: Idx, Data Diolah Penulis, 2018 


\section{Lampiran 5}

Hasil Uji Autokorelasi

Runs Test

\begin{tabular}{|l|r|}
\hline & $\begin{array}{c}\text { Unstandardized } \\
\text { Residual }\end{array}$ \\
\hline Test Value $^{\mathrm{a}}$ & -.00545 \\
Cases < Test Value & 38 \\
Cases >= Test Value & 38 \\
Total Cases & 76 \\
Number of Runs & 43 \\
Z & .924 \\
Asymp. Sig. (2-tailed) & .356 \\
\hline
\end{tabular}

a. Median

Sumber: Idx, Data Diolah Penulis, 2018

\section{Lampiran 6}

Hasil Uji Regresi Linear Berganda

Coefficients $^{a}$

\begin{tabular}{|c|c|c|c|c|c|c|c|}
\hline \multirow[b]{2}{*}{ Model } & \multicolumn{2}{|c|}{$\begin{array}{c}\text { Unstandardized } \\
\text { Coefficients }\end{array}$} & \multirow{2}{*}{$\begin{array}{c}\begin{array}{c}\text { Standardized } \\
\text { Coefficients }\end{array} \\
\text { Beta }\end{array}$} & \multirow[b]{2}{*}{$\mathrm{t}$} & \multirow[b]{2}{*}{ Sig. } & \multicolumn{2}{|c|}{ Collinearity Statistics } \\
\hline & $\mathrm{B}$ & Std. Error & & & & Tolerance & VIF \\
\hline 1 (Constant) & -4.021 & 2.339 & & -1.719 & .090 & & \\
\hline LnSIZE & .139 & .079 & .131 & 1.745 & .085 & .838 & 1.194 \\
\hline $\mathrm{KI}$ & -1.166 & .811 & -.109 & -1.438 & .155 & .824 & 1.214 \\
\hline $\mathrm{KP}$ & .256 & .079 & .247 & 3.249 & .002 & .822 & 1.216 \\
\hline $\mathrm{KD}$ & 3.019 & .771 & .278 & 3.917 & .000 & .944 & 1.059 \\
\hline PR & 8.471 & .991 & .630 & 8.546 & .000 & .874 & 1.144 \\
\hline
\end{tabular}

a. Dependent Variable: NP

Sumber: Idx, Data Diolah Penulis, 2018 


\section{Lampiran 7}

Hasil Uji t (Uji Parsial)

\begin{tabular}{|c|c|c|c|c|c|c|c|}
\hline \multicolumn{8}{|c|}{ Coefficients $^{\mathrm{a}}$} \\
\hline \multirow[b]{2}{*}{ Model } & \multicolumn{2}{|c|}{$\begin{array}{c}\text { Unstandardized } \\
\text { Coefficients }\end{array}$} & \multirow{2}{*}{$\begin{array}{c}\text { Standardized } \\
\text { Coefficients } \\
\text { Beta }\end{array}$} & \multirow[b]{2}{*}{$\mathrm{t}$} & \multirow[b]{2}{*}{ Sig. } & \multicolumn{2}{|c|}{ Collinearity Statistics } \\
\hline & B & Std. Error & & & & Tolerance & VIF \\
\hline 1 (Constant) & -4.021 & 2.339 & & -1.719 & .090 & & \\
\hline LnSIZE & .139 & .079 & .131 & 1.745 & .085 & .838 & 1.194 \\
\hline $\mathrm{KI}$ & -1.166 & .811 & -.109 & -1.438 & .155 & .824 & 1.214 \\
\hline $\mathrm{KP}$ & .256 & .079 & .247 & 3.249 & .002 & .822 & 1.216 \\
\hline KD & 3.019 & .771 & .278 & 3.917 & .000 & .944 & 1.059 \\
\hline PR & 8.471 & .991 & .630 & 8.546 & .000 & .874 & 1.144 \\
\hline
\end{tabular}

a. Dependent Variable: NP

Sumber: Idx, Data Diolah Penulis, 2018

\section{Lampiran 8}

Hasil Uji F (Uji Simultan)

ANOVA $^{\mathrm{a}}$

\begin{tabular}{|l|r|r|r|r|r|}
\hline & \multicolumn{1}{|c|}{$\begin{array}{c}\text { Sum of } \\
\text { Sodel }\end{array}$} & Squares & \multicolumn{1}{c|}{$\begin{array}{c}\text { Mean } \\
\text { Square }\end{array}$} & \multicolumn{1}{c|}{$\mathrm{F}$} & Sig. \\
\hline 1 Regression & 72.131 & 5 & 14.426 & 28.131 & $.000^{\mathrm{b}}$ \\
Residual & 35.898 & 70 & .513 & & \\
Total & 108.029 & 75 & & & \\
\hline
\end{tabular}

a. Dependent Variable: NP

b. Predictors: (Constant), PR, LnSIZE, KD, KI, KP

Sumber: Idx, Data Diolah Penulis, 2018

\section{Lampiran 9}

Hasil Uji Koefisien determinasi $\left(\mathrm{R}_{2}\right)$

Model Summary ${ }^{b}$

\begin{tabular}{|l|r|r|r|c|}
\hline Model & $\mathrm{R}$ & R Square & \multicolumn{1}{|c|}{$\begin{array}{c}\text { Adjusted R } \\
\text { Square }\end{array}$} & $\begin{array}{c}\text { Std. Error of the } \\
\text { Estimate }\end{array}$ \\
\hline 1 & $.817 \mathrm{a}$ & .668 & .644 & .7161173 \\
\hline
\end{tabular}

a. Predictors: (Constant), PR, LnSIZE, KD, KI, KP

b. Dependent Variable: NP

Sumber: Idx, Data Diolah Penulis, 2018 